There was some hope pending this litigation, however, that the supreme court of appeals would find some grounds to rule otherwise.

This same legislature had its attention called to another municipality in this state, namely Fairmont, a political hot-bed like other West Virginia cities, where not the slightest ethics is recognized in political contests. The scrambling parties disliking the practice of one party feasting with the other party famishing, with neither party knowing until after election which would draw the famine, decided in some of the localities to create a charter form of government with a bi-partisan board, that would permit both parties equal representation upon the governing board. Thus it would be feast for all forever. But alas! when the city of Fairmont had its election there was elected on the bi-partisan board two Democrats and two Progressives and the poor Republican politicians remained out in the cold. The politicians in other cities fared better. Immediately they became busy, suggested a non-partisan board and when they were defeated in an attempt to exercise the "recall," they marched with their drooping heads to the brilliant legislature that made history for West Virginia, in 1915, and pleaded for a new charter for Fairmont. The legislature, after weighing seriously the arguments of both sides in so much as matters pertaining to municipal government were of such great importance, decided in their wisdom to give Fairmont another new charter. This charter, too, has found its way into the courts and if this act is declared invalid it will be on the grounds that you cannot eliminate the voters by mental test and that the legislature did not follow the proper rules in the passage of the act. But for these apparent defenses the act would undoubtedly be sustained.

The advocates of municipal home rule are striving hard to create sentiment that will eventually result in an amendment to the constitution, to provide that any act passed by the legislature changing the form of government of any municipality shall not take effect until ratified by the majority vote of that municipality.

\title{
DENVER'S NEW CHARTER
}

\author{
BY ELLIS MEREDITH \\ Denver, Colorado ${ }^{1}$
}

$\mathrm{B}^{\mathrm{x}}$ Y AN overwhelmingly decisive vote Denver discarded the commission form of government May 9 and adopted a charter amendment which gives practically all executive power to the mayor and creates a city council of nine members.

\footnotetext{
${ }^{1}$ Ex-President, Denver election commission. See National Municipal Review, vol. iii, p. 668 .
} 
Before considering the new régime a word is in order by way of comfort to those who still pin their faith upon commission government. Even those who do not believe in it admit frankly that it did not have a fair trial in this city. It is based upon the theory that men of quite unusual capacity will be attracted by the opportunity for service, each commissioner being supreme in his own field, and able to make a record that stands clearly by itself. But in Denver the same vote that declared for the commission form declared also for the preferential ballot, and much to the disappointment of those who had seen in this so-called "fool-proof ballot" the realization of an "iridescent dream" it proved more like a nightmare. Party lines were wiped out to such an extent that no candidate could receive the support of any aggregation of people, and as few men are adepts in sounding their own praises this kind of personal campaigning was very obnoxious to those who might have given the city the best service. As a result those ideal candidates who, like good children are occasionally seen, but never heard, preferred to continue on the even tenor of their way, while men of lesser talent made the race.

As the five commissioners formed the council, and no one could make more than a guess as to who would be elected, and much of the success of the government must depend upon a council that could and would work together harmoniously, this was an added drawback, and the commission government failed as much on account of the uncertainty which is rendered certain by the preferential ballot, as because of any shortcomings of its own, or on the part of the commissioners who have been good officers, on the whole, even if none of them has given a brilliant administration of his own department or inaugurated any striking civic improvement in the council. It is a pity the commission form might not have had a fairer trial, for it was not without its advantages, and some 22,000 people voted to retain it.

The agitation for a change has been going on for some time. Two years ago this fall an attempt was made to recall the commissioner of safety. It was well known that it was fostered by an anti-Catholic organization, and members of that church, regardless of party, rallied to his support and re-elected him. The same element prepared an amendment calling for the election of city officials and filed it early this spring. When it became evident that there was to be an election Robert W. Speer, for eight years mayor of Denver, submitted an amendment to the charter, and shortly afterward the Republican organization of the city and county presented yet another amendment creating a city council of nine named in the charter, nominated W. W. Booth for mayor, named two of the commissioners for the offices of sheriff and treasurer and nominated a clerk and recorder.

The campaign soon demonstrated that the first, or Macy amendment was hopelessly out of the running. Very soon it became equally clear 
that the Booth amendment had no chance of adoption, and there were many evidences of the old alliance between the Republican organization and that of the Democrats, which was working enthusiastically for Mr. Speer. The only alternative left was to vote against all the amendments and various organizations: the independent voters league, the anti-civic center association, the anti-saloon league-the W. C. T. U., and many of the clergy urged the public to do this. A total of 54,496 votes were cast, registered as follows:

Macy amendment-For, 6,508; against, 45,408 .

Booth amendment-For, 5,659; against, 44,344.

Speer amendment-For, 30,891; against, 22,164.

No attempt was made to go into the courts. In spite of much bitterness during the campaign the city accepted the results philosophically, and even those most strenuously opposed to Mr. Speer, have decided that the best course for the present is one of "watchful waiting."

The new charter provides for a benevolent despotism. It does not repeal the initiative and referendum nor the recall. It doesn't even repeal the preferential ballot. It concentrates all the administrative powers in the hands of the mayor and all the legislative powers in the hands of the council, with an auditor independent of both. The present auditor serves until the end of his term, and next May his successor will be elected for a term of four years, also a council of nine members to be nominated and elected by districts for a term of two years. Four of the present council have been appointed by Mayor Speer and the other five by the Denver civic and commercial association, the trades assembly, the real estate exchange, the rotary club and the manufacturer's association, and while they have just organized and have had no time to formulate plans, the general public is well satisfied with the personnel of the council.

Four departments are created, the heads of which form the mayor's cabinet; they have charge respectively. of the improvements and parks, revenue, health and charity and safety and excise.

The mayor is given the power to appoint the heads of all administrative departments and the members of all commissions, boards and officers, and all persons in the employ of the city or county or any of the departments thereof whose salaries or compensations are not fixed in the charter amendments are declared to be employes and shall be appointed by the mayor or department head, and the mayor is given power to fill all vacancies. In other words, he is given complete power of appointment.

The one particular section which is nearest the heart of Mayor Speer is said to be entirely new in city governments in this country. It is short and somewhat vague, and sufficiently elastic to cover a very wide scope of endeavor, as anything has need to be when it is frankly experimental in character. Nothing is a greater mistake than hard and fast 
rules and limitations when embarking on an undertaking where precedents are few and success depends largely upon freedom to carry out a design that grows in the making. This section provides:

"There shall be, and hereby is, created an industrial bureau for the purpose of encouraging local industries and employment of labor. It shall be limited in its expenditures to the amount of money appropriated for its use by the city and county. It shall consist of the mayor and four members appointed by him, who shall serve without pay. This bureau shall be vested with full power of the city and county to encourage industries, stimulate trade and secure the employment of labor."

The idea of Mayor Speer, as he outlined it in his campaign, is that there are many small concerns engaged in manufacturing all sorts of things, and hampered in all sorts of ways. Sometimes there are obvious difficulties, and sometimes there are leaks that take away the profit. In one place he found the proprietor discharging a man, who almost begged to be retained. On investigation he found that the man was manufacturing an article used extensively in Denver, but imported. A little missionary work brought supply and demand together, and the employe kept his job. For months past the new mayor has been making a quiet investigation among the little shops and plants of the city, and now he has a well defined determination, rather than an exact plan, to help "to separate the men who want work from the men who won't work," and take care of both of them in the way that will be most beneficial to the community.

During his former administrations public improvements were pushed vigorously-beyond what many felt the city was able to bear. In the four years since he went out of office there has not been a great deal done in that direction. This is, perhaps, one of the innate weaknesses of commission government. Each commissioner wants all the funds he can get for his own department, and they are not willing to yield for the greater good of the community. So far as one can judge from his utterances Mayor Speer does not intend to launch out into any very extensive improvements which would call for increased taxation; already he has begun his promised era of economy by lopping off surplus clerks, consolidating departments, abolishing sinecures, and leaving the outside workers alone in the main. The day laborer, who makes parks and boulevards beautiful, is not trembling for his "job," even though the civil service, which is a poor thing under the Denver charter, does not protect him.

There is one most unusual condition following upon this election. No man has ever had more active opponents than Robert Speer, and his election was bitterly fought by men and women who are not "quitters," yet the prevailing opinion seems to be patient, rather than censorious. It is recognized that under this charter the mayor is supreme, and while there are not wanting those who are not looking for any good thing, 
let alone a millenium to come as a result of this election, still the general opinion is that the new administration should have a chance to demonstrate what the one man power can do, when it has a free field.

No man ever had a harder task than that which confronts Mayor Speer. It is not only a city to govern by new methods; he is a strong man, eager to try out some theories which he has long considered, and he has had the benefit of study and travel since leaving office. For a man of his character neither work nor responsibility has any terrors, but when it comes to breaking definitely with the host of the faithful hangers-on of the past, and turning a deaf ear to the friends who deserve much in the way of personal consideration from him, but nothing whatever from this city, this is much more difficult. Yet this is what he must do if he is to justify the faith of his friends and set at naught the criticism of his enemies. Economy cannot afford to give gratitude much house-room, yet to appear unmindful of past benefits is a thankless part. It is safe to say that no problem of city administration will give Mr. Speer more anxious moments than squaring his performance with the hopes of a multitude of people who expect to receive a public reward in return for votes loyally given.

In the meantime, the city is not troubling itself with any such abstract considerations. Under the prohibition law which went into effect last January it has been growing, building, beautifying, realizing a new ideal, and now that it has started out upon what it conceives to be a new era in its history, it has "thrown to the winds its fears" and gives every promise of a year of unexampled prosperity, in spite of the lugubrious predictions that always attend presidential elections. 